\title{
PENGARUH PENDEKATAN SAINTIFIK BERORIENTASI TRI KAYA PARISUDHA TERHADAP PENGUASAAN KONSEP IPA DAN KETERAMPILAN PROSES SAINS SISWA KELAS V SD DI GUGUS VII KECAMATAN SUKASADA KABUPATEN BULELENG TAHUN PELAJARAN 2018/2019
}

\author{
Ni Komang Suryani \\ Program Studi Pendidikan Guru Sekolah Dasar, Universitas Pendidikan Ganesha \\ komangsuryani97@gmail.com \\ Ndara Tanggu Renda \\ Program Studi Pendidikan Guru Sekolah Dasar, Universitas Pendidikan Ganesha \\ ndaratanggu.renda@undiksha.ac.id \\ I Made Citra Wibawa \\ Program Studi Pendidikan Guru Sekolah Dasar, Universitas Pendidikan Ganesha \\ imadecitra.wibawa@undiksha.ac.id
}

\begin{abstract}
Abstrak
Penelitian ini bertujuan untuk mengetahui pengaruh pendekatan saintifik berorientasi Tri Kaya Parisudha terhadap penguasaan konsep IPA dan keterampilan proses sains. Penelitian ini merupakan penelitian quasi experiment dengan desain nonequivalent post-test only control group. Populasi dalam penelitian ini adalah seluruh kelas V di Gugus VII Kecamatan Sukasada terdiri dari 6 kelas dengan jumlah siswa 144 orang. Sampel penelitian ini yaitu SD N 1 Selat di Anturan dengan jumlah siswa 27 orang sebagai kelompok eksperimen dan SD N 3 Selat di Anturan dengan jumlah siswa 33 orang dengan menggunakan teknik random sampling. Metode pengumpulan data penguasaan konsep IPA dikumpulkan menggunakan metode tes pilihan ganda dan data keterampilan proses sains dikumpulkan menggunakan tes esay. Data dianalisis menggunakan Manova dengan bantuan SPSS-22 for windows. Hasil penelitian menunjukkan bahwa: 1) terdapat pengaruh yang signifikan pendekatan saintifik berorientasi Tri Kaya Parisudha terhadap keterampilan proses sains pada siswa kelas V di Gugus VII Kecamatan Sukasada Kabupaten Buleleng Tahun Pelajaran 2018/2019 (Fhitung = 32,27 > Ftabel $=4,00)$, 2) terdapat pengaruh yang signifikan pendekatan saintifik berorientasi Tri Kaya Parisudha terhadap keterampilan proses sains pada siswa kelas V di Gugus VII Kecamatan Sukasada Kabupaten Buleleng Tahun Pelajaran 2018/2019 (Fhitung = 9,64 > Ftabel = 4,00), dan 3) terdapat pengaruh yang signifikan secara simultan pendekatan saintifik berorientasi Tri Kaya Parisudha terhadap penguasaan konsep IPA dan keterampilan proses sains pada siswa kelas V di Gugus VII Kecamatan Sukasada Kabupaten Buleleng Tahun Pelajaran 2018/2019 (0,000<0,05). Berdasarkan temuan tersebut, bahwa terdapat pengaruh yang signifikan secara simultan pendekatan saintifik berorientasi Tri Kaya Parisudha terhadap penguasaan konsep IPA dan keterampilan proses sains pada siswa kelas V SD Gugus VII Kecamatan Sukasada Kabupaten Buleleng Tahun Pelajaran 2018/2019.
\end{abstract}

Kata kunci: pendekatan saintifik, penguasaan konsep IPA, keterampilan proses sains, dan tri kaya parisudha

\begin{abstract}
This study aimed to determine the effect of Tri Kaya Parisudha oriented with scientific approach toward science concepts mastery and science process skills. This research was a quasi-experimental study with a nonequivalent post-test only control group design. The population in this study was all 5th grade student in 7th Gugus of Sukasada District consisted of 6 classes with 144 students. The sample of this research was SD N 1 Selat in Anturan with 27 students as the experimental group and SD N 3 Selat in Anturan with 33 students used random sampling techniques. The method of collecting data on mastery of science concepts was collected using multiple choice test methods and data on science process skills were collected using essay tests. Data were analyzed by used Manova which assestedby SPSS-22 for windows. The results showed that: 1) There was a significant influence on Tri Kaya Parisudha oriented scientific approach to science process skills in 5th grade student in 7th Gugus Sukasada District (F count $=32.27>$ Ftable $=4.00)$, 2) There was a significant influence on the approach Scientific oriented Tri Kaya Parisudha towards science process skills in 5th grade student in 7th Gugus Sukasada District (F count $=9.64>$ Ftable $=4.00)$, and 3) There was a significant effect simultaneously Tri Kaya Parisudha oriented scientific approach in mastering the science concept and science process skills in 5th grade student in 7th Gugus. Based on these findings, there were significant simultaneous effects of Tri Kaya Parisudha oriented scientific approach toward science concepts mastery and science process skills in fifth grade students of elementary school in 5th grade student in 7th Gugus VII Sukasada of sub-District $(0,000<0,05)$.
\end{abstract}

Keywords: science process skills, science concepts mastery, scientific approach, tri kaya parisudha. 


\section{Pendahuluan}

Pendidikan mempunyai peran yang sangat penting bagi kehidupan manusia, melalui pendidikan dapat mendorong peningkatan mutu kualitas manusia dalam meningkatkan kompetensi kognitif, afektif, maupun psikomotor. Untuk meningkatkan kualitas sumber daya manusia dalam pendidikan, ada pun hal yang harus diperhatikan yaitu tantangan pendidikan di era revolusi industri 4.0 yang menuntut perubahan cara belajar, pola berpikir serta cara bertindak siswa dalam mengembangkan inovasi kreatif diberbagai bidang ilmu pengetahuan. Hal ini sejalan dengan Sistem Pendidikan Nasional UU No. 20 Tahun 2003 yang tercantum dalam pasal 1 ayat 1.

Agar dapat mencapai tujuan pendidikan, maka diberikan mata pelajaran-mata pelajaran seperti yang ditetapkan dalam pasal 37 ayat 1 tentang Sistem Pendidikan Nasional, salah satu mata pelajaran yang diajarkan di sekolah dasar adalah Pendidikan IPA. IPA merupakan mata pelajaran yang membekali siswa dengan kompetensi pengetahuan dan keterampilan yang dibutuhkan oleh mereka untuk mencari tahu tentang alam dan mempelajari diri sendiri. Hal ini sejalan dengan pendapat Agustiana \& Tika, (2013) menyatakan bahwa IPA berhubungan dengan cara mencari tahu tentang alam secara sistematis sehingga IPA bukan hanya pengusaaan kumpulan pengetahuan yang berupa fakta, konsep, atau prinsip saja tetapi juga merupakan suatu proses penemuan. Dalam kurikulum 2013, mata pelajaran IPA terintegrasi dengan beberapa mata pelajaran lainnya. Adapun tujuan pembelajaran kurikulum 2013 yang tercantum dalam Permendikbud Nomor 67 Tahun 2013.

Berbagai upaya yang telah dilakukan guru untuk mencapai tujuan pendidikan yang telah ditetapkan, namun belum membuahkan hasil yang optimal dalam meningkatkan mutu pendidikan di Indonesia. Permasalahan pendidikan Indonesia pada pelajaran IPA dapat dibuktikan dari hasil tes dan evaluasi PISA 2015 yang menunjukkan bahwa prestasi literasi IPA siswa Indonesia tergolong rendah, hasil yang diperoleh sebesar 403 yang berada pada rangking 62 dari 70 negara. Berdasarkan kenyataan tersebut, terlihat bahwa kemampuan kognitif siswa di Indonesia masih sangat rendah dibandingkan dengan negara-negara lain. Artinya rendahnya literasi IPA siswa dipengaruhi oleh penguasaan konsep yang masih lemah serta siswa kurang mampu menyelesaikan permasalahan kontekstual yang dihadapinya. Rendahnya literasi IPA siswa disebabkan oleh beberapa faktor salah satunya temuan Depdiknas tahun 2008 masih tetap terjadi sampai saat ini, pembelajaran IPA yang terjadi dilapangan masih belum mampu untuk mengembangkan kemampuan siswa secara maksimal karena kegiatan pembelajaran yang ada masih berpusat pada guru. Berdasarkan kenyataan ketika dilaksanakan wawancara, observasi, dan pencatatan dokumen di SD Gugus VII Kecamatan Sukasada diperoleh informasi mengenai beberapa permasalahan pada mata pelajaran IPA. Hasil wawancara dengan guru-guru kelas V SD dan observasi di Gugus VII Kecamatan Kabupaten Buleleng, yang dilaksanakan pada tanggal 7-12 Januari 2019 yaitu 1) kesulitan dalam menerapkan kurikulum 2013,2) kurangnya pehaman siswa untuk mengaitkan materi yang diperoleh dengan permasalahan yang dihadapi, 3) siswa kurang aktif dalam mengikuti pelajaran IPA, 4) pada saat kerja kelompok didominasi oleh siswa yang diam (menunggu hasil), 5) rendahnya penguasaan konsep IPA dan keterampilan proses sains. Diketahui pencatatan dokumen guru kelas V yaitu nilai rata-rata penguasaan konsep IPA dan keterampilan proses sains siswa di kelas V SD di Gugus VII Kecamatan Kabupaten Buleleng berada pada rentangan 64,6-68,4. Jika dikonversikan terhadap skala penilaian acuan patokan (PAP) (dalam Agung, 2014:251), rentangan tersebut berada pada kategori cukup. Hal ini menandakan bahwa nilai rata-rata UAS IPA siswa kelas V SD di Gugus VII Kecamatan Kabupaten Buleleng dapat diklasifikasikan penguasaan konsep IPA dan keterampilan proses sains rendah.

Rendahnya penguasaan konsep IPA dan keterampilan proses sains merupakan masalah yang harus diatasi. Untuk mengatasinya dapat menggunakan salah satu pendekatan pembelajaran yang tepat, diantaranya adalah pendekatan saintifik karena pendekatan saintifik dapat memberikan kesempatan kepada siswa untuk menggali pengetahuannya sendiri melalui kegiatan mengamati, menanya, mengumpulkan data, mengolah data, dan mengkomunikasikan data yang diperoleh dari analisis. Kurniasih \& Sani (2014) menyatakan pendekatan saintifik diyakini sebagai titian emas perkembangan dan pengembangan sikap, keterampilan, dan pengetahuan peserta didik. Pernyataan tersebut sejalan dengan pendapat Daryanto (2014:51) menjelaskan bahwa: pembelajaran dengan pendekatan saintifik adalah proses pembelajaran yang dirancang sedemikian rupa agar peserta didik secara aktif mengkonstruksikan konsep, hukum atau prinsip melalui tahapan-tahapan mengamati (mengidentifikasi atau menemukan masalah), merumuskan masalah, mengajukan atau merumuskan hipotesis), mengumpulkan data dengan berbagai teknik, menganalisis konsep, hukum atau prinsip yang "ditemukan".

Melalui penerapan pendekatan saintifik peran sentral guru dapat diminimalisir karena semua siswa akan terlibat untuk dapat menyelesaikan permasalahan yang diberikan oleh guru. Pada tahap mengamati siswa melatih kesungguhan, ketelitian, dam mencari informasi, berupa kemampuan memahami (C2) dan menerapkan (C3) apa yang sedang diamati. Pada tahap menanya siswa melatih kreativitas, rasa ingin tahu, kemampuan merumuskan pertanyaan tentang informasi dari apa yang diamati atau pertanyaan untuk mendapatkan informasi berupa kemampuan menerapkan (C3). Pada tahap mengumpulkan informasi siswa melatih menerapkan (3) kemampuan mengumpulkan informasi dari berbagai cara yang dipelajari. Pada tahap mengasosiasikan atau mengolah informasi melatih siswa kemampuan menerapkan (C3) prosedur dan kemampuan berpikir kritis dalam memecahkan masalah dan menganalisis data (C4). Pada tahap mengkomunikasikan melatih siswa mengembangkan kemampuan berbahasa yang baik dan benar dan menilai (5) sejauh mana pemahaman siswa 
terhadap materi yang dipelajari. Kemampuan siswa dalam menguasai tidak hanya sekedar tahu saja, tetapi bisa melakukan (C6) kemampuan tersebut dalam kehidupan sehari-hari (Kurniasih \& Sani, 2014).

Pendekatan saintifik lebih efektif bila dipadukan dengan konsep Tri Kaya Parisudha dalam proses pembelajaran IPA. Melihat generasi sekarang, dalam berbicara dengan orang yang lebih tua terkadang kurang sopan bahkan mengnggap orang yang lebih tua sebagai teman sejawatnya sehingga berbicara seenaknya. Selain berbicara dalam berpikir dan bertindak juga kurang dikendalikan dan dikontrol. Untuk memperbaiki hal tersebut konsep Tri Kaya Parisudha yang sangat penting untuk diterapkan dalam pembelajaran, sehingga mampu mengarahkan siswa untuk belajar berpikir, berkata, dan berbuat yang baik.

Tri Kaya Parisudha merupakan unsur tradisi bali yang telah memiliki sejarah panjang yang dijadikan pedoman dalam bertingkah laku yang benar. Tri Kaya Parisudha adalah tiga perbuatan yang yang harus disucikan (Agustiana \& Tika, 2013). Bagian-bagian dari Tri Kaya Parisudha yaitu berpikir, berkata, dan berbuat yang baik. Pikiran, perkataan, dan perbuatan yang kotor harus dikendalikan agar pikiran, perkataan, dan perbuatan menjadi baik dan benar. Tri Kaya Parisudha harus diterapkan dalam kehidupan sehari-hari seperti dalam kegiatan pendidikan, yang akan menghasilkan siswa-siswa berkarakter. Hal ini sejalan dengan Peraturan Presiden No. 87 Tahun 2017 pasal 1 ayat 1 tentang Penguatan Pendidikan Karakter. Penanaman pendidikan karakter dalam Tri Kaya Parisudha tidak hanya sebatas pengarahan dari guru kepada siswa, namun guru sebagai panutan dapat menerapkan nilai-nilai Tri Kaya Parisudha. Dengan demikiaan jika Tri Kaya Parisudha dipadukan dengan pendekatan saintifik dalam proses pembelajaran IPA akan meningkatkan keterampilan proses sains dan pengusaan konsep IPA, serta dapat menanamkan nilai-nilai Tri Kaya Parisudha.

Menyikapi dari permasalahan yang telah dipaparkan di atas, mendorong peneliti untuk melakukan penelitian eksperimen dengan judul "Pengaruh Pendekatan Saintifik berorientasi Tri Kaya Parisudha terhadap Penguasaan Konsep IPA dan Keterampilan Proses Sains pada Siswa Kelas V SD di Gugus VII Kecamatan Sukasada Tahun Pelajaran 2018/2019”.

\section{Metode}

Penelitian ini dillaksanakan di SDN 1 dan 3 Selat gugus VII Kecamatan Sukasada. Subjek dari penelitian ini adalah siswa kelas V SD N 1 Selat yang berjumlah 27 orang dan SD N 3 Selat yang berjumlah 33 orang. Penelitian ini melibatkan dua varibel, yaitu varibel bebas dan variabel terikat. Variabel bebas dalam penelitian ini adalah pendekatan saintifik berorientasi Tri Kaya Parisudha dan variabel terikat dalam penilitian ini adalah penguasaan konsep IPA dan keterampilan proses sains.

Penelitian ini termasuk quasi experiment karena tidak semua variabel yang muncul dalam kondisi eksperimen dapat diatur dan dikontrol secara ketat. Rancangan eksperimen yang digunakan adalah rancangan nonequivalent post-test only control group design. Metode pengumpulan data dalam penelitian ini metode tes untuk mendapatkan hasil keterampilan proses sains dan penguasaan konsep IPA. Pengumpulan data penguasaan konsep IPA dengan menggunakan instrumen tes pilihan ganda dan keterampilan proses sains dengan menggunakan intrumen tes esay. Data yang diperoleh kemudian dianalisis dengan menggunakan analisis deskriptif dengan mencari mean, modus, median, dan standar deviasi dari sampel. Selain itu, data yang diperoleh juga diuji dengan uji prasyarat analisis data, yaitu uji normalitas, uji homogenitas, dan uji korelasi.

Uji normalitas dilakukan untuk menguji bahwa sampel benar-benar berasal dari populasi yang sama yaitu berdistribusi normal. Uji normalitas data untuk hasil penguasaan konsep IPA dan keterampilan proses sains siswa digunakan analisis Chi-Kuadrat. Uji homogenitas dilakukan untuk mengetahui sebaran data homogen atau tidak. Uji homogenitas untuk kedua kelompok digunakan uji F. Sedangkan uji korelasi dilakukan untuk mengetahui hubungan/korelasi yang signifikan antar variabel. Uji korelasi antar variabel terikat dilakukan dengan menggunakan uji product moment dengan taraf signifikansi 5\%, setelah uji prasayarat dilanjutkan dengan pengujian hipotesis. Teknik analisis data yang digunakan untuk menguji hipotesis dalam penelitian ini, yaitu menggunakan teknik analisis Anava A dan Manova dengan bantuan SPSS-22 for windows.

\section{Hasil dan Pembahasan}

Hasil dari analisis data terhadap hasil penguasaan konsep IPA dan keterampilan proses sains siswa kelompok eksperimen dan kontrol dapat dilihat pada tabel berikut ini.

Tabel 1. Deskripsi Data Hasil Penguasaan Konsep IPA dan Keterampilan Proses Sains

\begin{tabular}{lcccc}
\hline \multirow{2}{*}{ Statistik } & \multicolumn{2}{c}{ Hasil Penguasaan Konsep IPA } & \multicolumn{2}{c}{ Keterampilan Proses Sains } \\
\cline { 2 - 5 } & Kelas Eksperimen & Kelas Kontrol & Kelas Eksperimen & Kelas Kontrol \\
\hline $\mathrm{N}$ & 27 & 32 & 27 & 32 \\
Mean & 81,48 & 70,09 & 83,67 & 80,66 \\
Median & 79,1 & 72,3 & 82,1 & 74,5 \\
Modus & 79,3 & 71,9 & 82,5 & 77,3 \\
Standar Deviasi & 5,65 & 6,04 & 6,12 & 5,64
\end{tabular}




\begin{tabular}{lcccc}
\hline \multirow{2}{*}{ Statistik } & \multicolumn{2}{c}{ Hasil Penguasaan Konsep IPA } & \multicolumn{2}{c}{ Keterampilan Proses Sains } \\
\cline { 2 - 5 } & Kelas Eksperimen & Kelas Kontrol & Kelas Eksperimen & \multirow{2}{*}{ Kelas Kontrol } \\
\hline Varians & 31,91 & 36,52 & 37,49 & 31,92 \\
Range & 24 & 21 & 21 & 21 \\
Minimum & 70 & 60 & 74 & 74 \\
Maksimal & 93 & 80 & 94 & 94 \\
\hline
\end{tabular}

Berdasarkan Tabel 1. diketahui bahwa nilai rata-rata hasil penguasaaan konsep IPA kelas eksperimen adalah 81,48 , dan kelas control adalah 70,09. Sedangkan nilai rata-rata hasil keterampilan proses sains kelas eksperimen adalah 83,67, dan kelas kontrol adalah 80,66. Selanjutnya data hasil penguasaan konsep IPA dan keterampilan proses sains disajikan ke dalam histogram seperti gambar berikut..

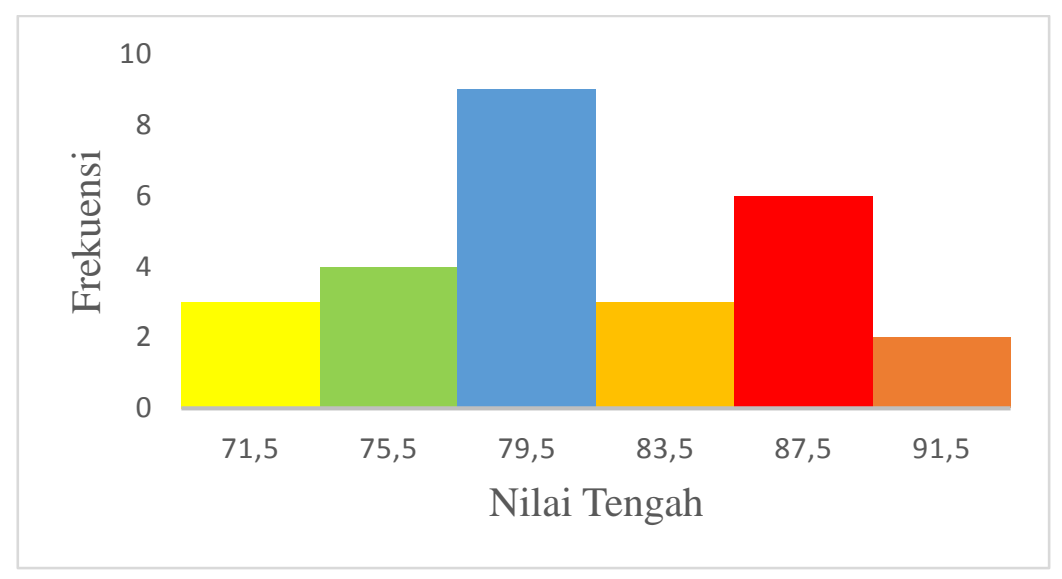

Gambar 1. Histogram Hasil Penguasaan Konsep IPA Kelompok Eksperimen

Berdasarkan grafik histogram gambar 1, dapat diketahui bahwa 3 orang siswa memiliki nilai antara 7073,4 orang siswa memiliki nilai antara 74-77, 9 orang siswa memiliki nilai antara 78-81, 3 orang siswa memiliki nilai antara 82-85, 6 orang siswa memiliki nilai antara 86-89, dan 2 orang siswa memiliki nilai antara 90-93.

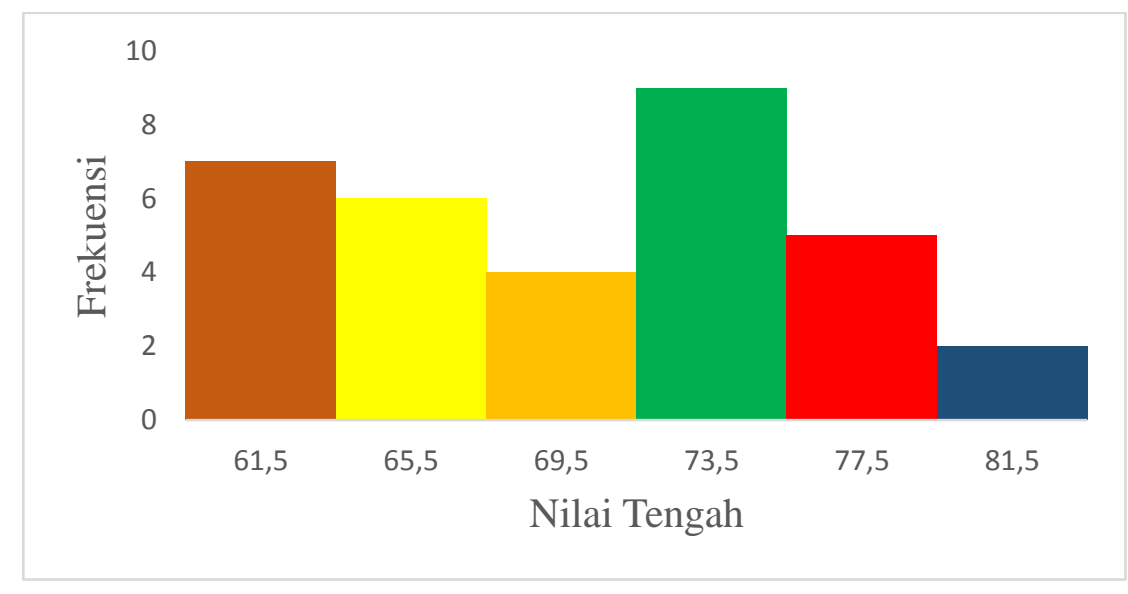

Gambar 2. Histogram Hasil Penguasaan Konsep IPA Kelompok Kontrol

Berdasarkan grafik histogram gambar 2, dapat diketahui bahwa 7 orang siswa memiliki nilai antara 6063, 4 orang siswa memiliki nilai antara 64-67, 6 orang siswa memiliki nilai antara $68-71,4$ orang siswa memiliki nilai antara 72-75, 9 orang siswa memiliki nilai antara 76-79, dan 5 orang siswa memiliki nilai antara 80-83. 


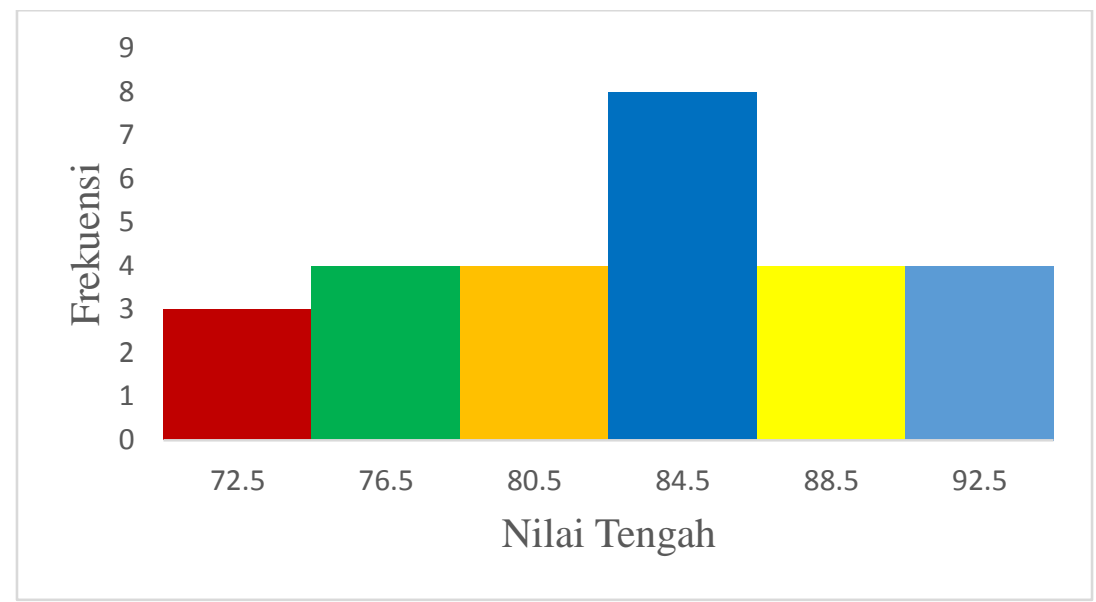

Gambar 3. Histogram Keterampilan Proses Sains Kelompok Eksperimen

Berdasarkan grafik histogram gambar 3, dapat diketahui bahwa 3 orang siswa memiliki nilai antara 7174,4 orang siswa memiliki nilai antara 75-78, 4 orang siswa memiliki nilai antara 79-82, 8 orang siswa memiliki nilai antara 83-86, 4 orang siswa memiliki nilai antara 87-90, dan 4 orang siswa memiliki nilai antara 91-94.

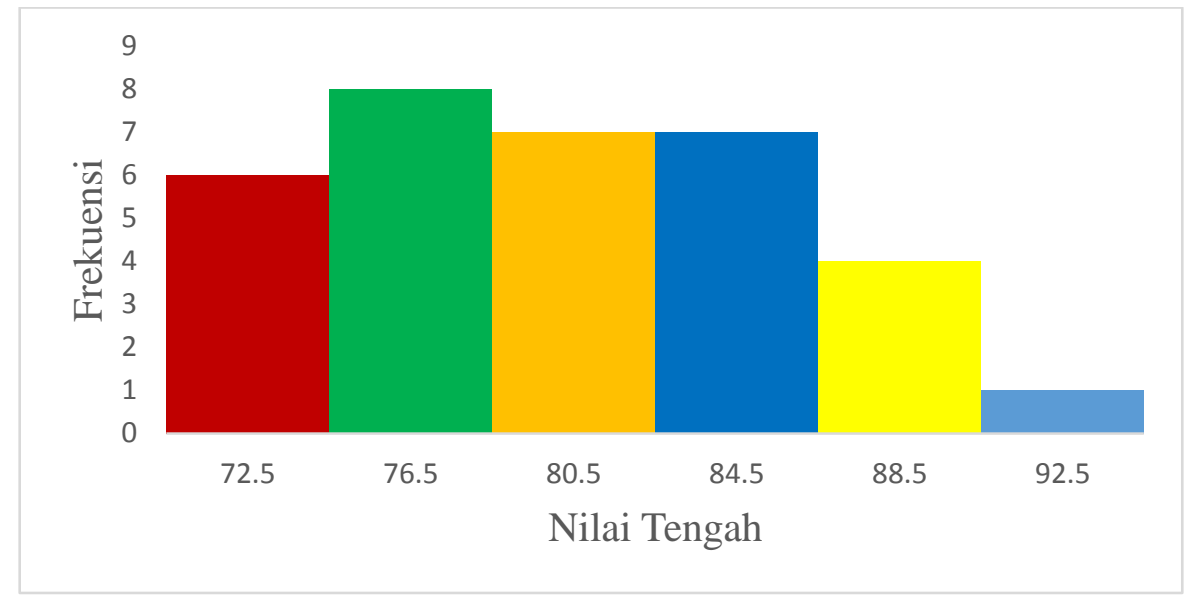

Gambar 4. Histogram Hasil Keterampilan Proses Sains Kelompok Kontrol

Berdasarkan grafik histogram 4.4, dapat diketahui bahwa 6 orang siswa memiliki nilai antara 71-74, 8 orang siswa memiliki nilai antara 75-78, 7 orang siswa memiliki nilai antara 79-82, 7 orang siswa memiliki nilai antara 83-86, 4 orang siswa memiliki nilai antara 87-90, dan 1 orang siswa memiliki nilai antara 91-94.

Sebelum melakukan uji hipotesis terhadap hipotesis nol (H0), maka dilakukan uji prasyarat yaitu uji normalitas, uji homogenitas, dan uji korelasi. Analisis uji normalitas data pada penelitian ini digunakan analisis Chi-Kuadrat dengan kriteria maka, data dinyatakan berdistribusi normal. Rekapitulasi uji normalitas data hasil penguasaan konsep IPA dan keterampilan proses sains dapat dilihat pada tabel berikut.

Tabel 2. Rekapitulasi Uji Normalitas Penguasaan Konsep IPA dan Keterampilan Proses Sains

\begin{tabular}{lccc}
\hline \multicolumn{1}{c}{ Kelompok Data } & $\chi^{2}{ }_{\text {hint ung }}$ & $\chi_{\text {tabel }}^{2}$ & Keterangan \\
\hline Penguasaan konsep IPA kelompok eksperimen & 7,815 & 7,746 & Normal \\
Penguasaan konsep IPA kelompok kontrol & 7,815 & 5,570 & Normal \\
Keterampilan proses sains kelompok eksperimen & 7,815 & 4,809 & Normal \\
Keterampilan proses sains kelompok kontrol & 7,815 & 6,123 & Normal \\
\hline
\end{tabular}

Berdasarkan hasil perhitungan dengan menggunakan rumus Chi-Kuadrat sesuai tabel 4.9, diperoleh hasil uji normalitas penguasaan konsep IPA pada kelompok eksperimen adalah 7,746. Selanjutnya dikonsultasikan ke tabel Chi-Kuadrat pada taraf signifikansi 5\% dengan $\mathrm{dk}=6-2-1=3$, didapatkan harga Chi-Kuadrat 7,815, dan Chi-Kuadrat hitung sebesar 7,746. Sehingga dapat disimpulkan bahwa $(7,746)<$ $(7,815)$. Karena harga Chi-Kuadrat hasil penelitian lebih kecil dari pada Chi-Kuadrat tabel, maka dapat 
disimpulkan bahwa data hasil penelitian tersebut berdistribusi normal. Pada kelompok kontrol diperoleh = 5,570 dan dengan taraf signifikansi 5\% dan $\mathrm{dk}=3$ adalah 7,815. Hal ini berarti lebih kecil dari $\quad(5,570<$ 7,815), sehingga data penguasaan konsep IPA kelompok kontrol berdistribusi normal. Pada data keterampilan proses sains kelompok eksperimen diperoleh $=4,809$ dan $=7,815$ dengan taraf signifikan $5 \%$ dan dk $=3$. Hal ini berarti lebih kecil dari $(4,809<7,815)$, sehingga data keterampilan proses sains kelompok eksperimen berdistribusi normal. Pada kelompok kontrol diperoleh $=6,123$ dan $=7,815$ dengan taraf signifikan 5\% dan $\mathrm{dk}$ $=3$. Hal ini berarti lebih kecil dari $(6,123<7,815)$, sehingga data keterampilan proses sains kelompok eksperimen berdistribusi normal.

Uji homogenitas dilakukan terhadap varians pasangan anta kelompok eksperimen dan kontrol. Uji yang digunakan adalah uji-F dengan kriteria data homogen jika Fhitung < Ftabel. Rekapitulasi uji homegenitas data hasil penguasaan konsep IPA dan keterampilan proses sains dapat dilihat pada tabel berikut.

Tabel 3. Uji Rekapitulasi Uji Homogenitas Penguasaan Konsep IPA dan Keterampilan Proses Sains

\begin{tabular}{lccc}
\hline \multicolumn{1}{c}{ Kelompok data } & Varians $\left(\mathrm{S}^{2}\right)$ & $\mathrm{F}_{\text {hitung }}$ & $\mathrm{F}_{\text {tabel }}$ \\
\hline Penguasa an konsep IPA kelompok eksperimen & 31,91 & 1,14 & Keterangan \\
Penguasa an konsep IPA kelompok kontrol & 36,52 & & Homogen \\
Keterampilan proses sains kelompok eksperimen & 37,49 & 1,17 & 4,01 \\
Keterampilan proses sains kelompok kontrol & 31,92 & Homogen \\
\hline
\end{tabular}

Berdasarkan perhitungan di atas, didapatkan harga Fhitung sebesar 1,14. Selanjutnya harga Fhitung tersebut dibandingkan dengan Ftabel pada taraf signifikan 5\%. Dengan df1 $=\mathrm{k}-1=2-1=1$, df $2=\mathrm{n}-\mathrm{k}=60-2=$ 58, maka Ftabel pada pada taraf signifikansi 5\% adalah 4,01. Nilai Ftabel $=4,01$, jika dibandingkan dengan Fhitung $=1,14$ menunjukkan Fhitung $(1,14)<$ Ftabel $(4,01)$, sehingga H0 diterima dan dapat disimpulkan varian data penguasaan konsep IPA kelompok eksperimen dan kelompok kontrol adalah homogen. Untuk keterampilan proses sains didapatkan harga Fhitung sebesar 1,17. Selanjutnya harga Fhitung tersebut dibandingkan dengan Ftabel pada taraf signifikan 5\%. Dengan df1 $=\mathrm{k}-1=2-1=1$, df2 $=\mathrm{n}-\mathrm{k}=60-2=58$, maka Ftabel pada pada taraf signifikansi 5\% adalah 4,01. Nilai Ftabel = 4,01, jika dibandingkan dengan Fhitung $=1,17$ menunjukkan Fhitung $(1,17)<$ Ftabel $(4,01)$, sehingga H0 diterima dan dapat disimpulkan varian data keterampilan proses sains kelompok eksperimen dan kelompok kontrol adalah homogen.

Uji korelasi antar variabel terikat dilakukan untuk mengetahui hubungan/korelasi yang signifikan antar variabel. Jika tidak ada hubungan/korelasi yang cukup tinggi, berarti tidak ada aspek yang sama diukur pada variabel tersebut dengan kata lain kedua variabel tersebut berbeda. Rekapitulasi hasil uji korelasi antar variabel terikat dengan menggunakan uji product moment dapat dilihat pada tabel berikut.

Untuk mengetahui pengaruh pendekatan saintifik beorientasi Tri Kaya Parisudha terhadap penguasaan konsep IPA dan keterampilan proses sains siswa, dilakukan pengujian terhadap hipotesis ketiga dengan menggunakan Manova (Multivariate Analysis of Varians) dengan bantuan SPSS 22 forr windows. Adapun ringkasan yang diperoleh dari hasil analisis menggunakan Manova dapat dilihat pada tabel berikut.

Tabel 7. Ringkasan Hasil Analisis Manova

\begin{tabular}{llrrrrr} 
& & \multicolumn{1}{c}{ Value } & \multicolumn{1}{c}{ F } & \multicolumn{1}{c}{ Hypothesis df } & \multicolumn{1}{c}{ Error df } & Sig. \\
\hline Intercept & Pillai's Trace & .997 & $9130.269^{\mathrm{b}}$ & 2.000 & 57.000 & .000 \\
& Wilks' Lambda & .003 & $9130.269^{\mathrm{b}}$ & 2.000 & 57.000 & .000 \\
& Hotelling's Trace & 320.360 & $9130.269^{\mathrm{b}}$ & 2.000 & 57.000 & .000 \\
& Roy's Largest Root & 320.360 & $9130.269^{\mathrm{b}}$ & 2.000 & 57.000 & .000 \\
Kelompok & Pillai's Trace & .454 & $23.699^{\mathrm{b}}$ & 2.000 & 57.000 & .000 \\
& Wilks' Lambda & .546 & $23.699^{\mathrm{b}}$ & 2.000 & 57.000 & .000 \\
& Hotelling's Trace & .832 & $23.699^{\mathrm{b}}$ & 2.000 & 57.000 & .000 \\
& Roy's Largest Root & & & & & \\
& & .832 & $23.699^{\mathrm{b}}$ & 2.000 & 57.000 & .000
\end{tabular}

a. Design: Intercept + Kelompok

b. Exact statistic

Berdasarkan hasil analisis pada tabel 7, nilai F Pillai's Trace, Wilks' Lambda, Hotelling's Trace, Roy's Largest Root adalah 23,699 seluruhnya memiliki signifikansi 0,000 dan lebih kecil dari 0,05 $(0,000<0,05)$, sehingga H0 ditolak dan H1 diterima. Berdasarkan hasil analisis uji hipotesis ketiga dapat disimpulkan bahwa terdapat pengaruh yang signifikan secara simultan pendekatan saintifik berorientasi Tri Kaya Parisudha terhadap 
penguasaan konsep IPA dan keterampilan proses sains pada siswa kelas V SD Gugus VII Kecamatan Kabupaten Buleleng.

Hasil analisis data penguasaan konsep IPA menunjukkan terdapat pengaruh yang signifikan pendekatan saintifik berorientasi Tri Kaya Parisudha terhadap penguasaan konsep IPA. Sejalan dengan pendapat Daryanto (2014:51) memaparkan bahwa pembelajaran dengan menggunakan pendekatan saintifik adalah proses pembelajaran yang dirancang agar anak dapat secara aktif mengkonstruksi konsep melalui tahapan, mengamati, merumuskan masalah, mengumpulkan data, menganalisis data, dan dapat menarik kesimpulan dari berbagai materi pembelajaran. Pendekatan saintifik lebih baik jika dipadukan dengan Tri Kaya Parisudha, karena nilainilai yang terkandung dapat diajarkan secara tidak langsung pada setiap kegiatan pembelajaran IPA melalui pendekatan saintifik. Hal ini sejalan dengan Agustiana \& Tika (2013:327) menyatakan, "konsep Tri Kaya Parisudha sangat perlu diajarkan pada peserta didik, karena konsep Tri Kaya Parisudha merupakan landasan bagi metode ilmiah dan menunjang cara berpikir IPA".

Pembelajaran IPA dengan menggunakan pendekatan saintifik berorientasi Tri Kaya Parisudha di kelas eksperimen yaitu pertama, kegiatan mengamati siswa mampu melatih diri untuk melihat dan menginggat apa yang sedang diamati. Ranah kognitif yang dikembangkan dalam kegiatan mengamati adalah C1 (mengingat) dan jika dipadukan dengan Tri Kaya Parisudha, kegiatan mengamati termasuk dalam manacika yiatu siswa dapat berpikir dengan benar tentang apa yang telah diamati. Hal ini sejalan dengan pernyataan Utamil dan Selly (2018:1554) menyatakan bahwa pembelajaran dengan pendekatan saintifik bertujuan untuk memungkinkan siswa berpikir secara ilmiah, logis, dan kritis untuk dapat menerapkan konsep IPA dalam kehidupan sehari-hari.

Kedua, kegiatan menanya mampu melatih siswa untuk menanyakan hal-hal yang kurang dipahami atau bertanya untuk mendapatkan informasi, rasa ingin tahu, dan menyatakan pendapatnya. Ranah kognitif yang dikembangkan adalah C3 (menerapkan) dan jika dipadukan dengan Tri Kaya Parisudha, kegiatan menanya termasuk dalam wacika yaitu siswa dapat menyatakan pendapatnya dengan benar dan masuk akal serta dapat mengghargai pendapat temannya. Hal ini sejalan dengan pendapat Machin (2014:31) menyatakan bahwa "melalui bertanya dikembangkan rasa ingin tahu peserta didik". Ketiga, yaitu kegiatan mengumpulkan informasi siswa dilatih untuk mencari informasi sumber lain di buku dan melakukan eksperimen. Ranah kognitif yang dikembangkan adalah C3 (menerapkan) dan C5 (mengevaluasi) serta jika dipadukan dengan Tri Kaya Parisudha kegiatan mengumpulkan informasi termasuk dalam kayika yaitu melakukan tindakan yang benar. Hal ini sejalan dengan Kemendikbud (dalam Setiawan, 2018:120) mengumpulkan informasi merupakan proses mencari jawaban dari pertanyaan-pertanyaan yang disampaikan anak pada tahap menanya.

Keempat, mengolah informasi siswa dilatih untuk mengelola informasi yang diperoleh atau diamati dan berdiskusi. Ranah kognitif yang dikembangkan adalah C4 (menganalisis) dan C6 (mencipta) serta jika dipadukan dengan Tri Kaya Parisduha, kegiatan mengolah informasi termasuk manacika dan wacika. Kelima, kegiatan mengkomunikasikan siswa dilatih untuk menyampaikan hasil pengamatan atau kesimpulan secara lisan, tertulis atau media lainnya. Ranah kognitif yang dikembangkan adalah C2 (memahami) dan jika dipadukan dengan Tri Kaya Parisudha termasuk dalam wacika. Hal ini sejalan Hosnan (Batmalo, 2016:476) menyatakan bahwa kegiatan yang dilaksanakan dalam proses pembelajaran adalah menyampaikan hasil pengamatan, kesimpulan berdasarkan hasil pengamatan, kesimpulan berdasarkan hasil analisis secara lisan, tertulis, atau media lainnya.

Hasil analisis data keterampilan proses sains penelitian menunjukkan terdapat pengaruh yang signifikan pendekatan saintifik berorientasi Tri Kaya Parisudha terhadap keterampilan proses sains. Langkah-langkah pembelajaran pendekatan saintifik berorienatasi Tri Kaya Parisudha pada keterampilan proses sains yaitu pertama, kegiatan mengamati (observasi) mampu melatih siswa untuk mengumpulkan fakta yang relevan dengan menggunakan alat indera. Ranah kognitif yang dikembangkan adalah C3 (menerapkan) dan jika dipadukan dengan Tri Kaya Parisudha termasuk dalam kayika yaitu siswa dapat bertindak dengan benar dan sesuai dengan apa yang diamati. Kedua, kegiatan menanya mampu melatih siswa untuk merumuskan pertanyaan tentang hal yang belum dipahami atau untuk mendapatkan informasi. Ranah kognitif yang dikembangkan adalah C6 (membuat) dan jika dipadukan dengan Tri Kaya Parisudha termasuk dalam manacika dan kayika yaitu siswa dapat berpikir dan berbuat dengan benar dan sesuai dengan apa yang diamati. Hal ini sejalan dengan pernyataan Permendikbud No 81a yaitu "kemampuan merumuskan pertanyaan untuk membentuk pikiran kritis yang perlu untuk hidup cerdas dan sepanjang hayat".

Ketiga, kegiatan menggumpulkan informasi mampu melatih siswa untuk mencari perbedaan, persamaan, membandingkan, dan mengelompokkan. Ranah kognitif yang dikembangkan adalah C2 (memahami) dan C5 (mengevaluasi) serta dipadukan dengan Tri Kaya Parisudha termasuk dalam manacika dan kayika yaitu dapat berpikir dan bertindak dengan benar dan tepat. Keempat, kegiatan mengolah informasi mampu melatih siswa untuk menentukan alat dan bahan yang digunakan, mengamati, mengukur, dan mengolah. Ranah kognitif yang dikembangkan adalah C3 (menerapkan), C4 (menganalisis), dan C5 (mengevaluasi) serta dipadukan dengan Tri Kaya Parisduha termasuk dalam manacika, wacika, dan kayika yaitu dapat berpikir, berkata, dan bertindak dengan benar. Kelima, kegiatan komunikasi siswa dilatih untuk menjelaskan hasil percobaan. Ranah kognitif yang dikembangkan adalah C2 (memahami) dan jika dipadukan dengan Tri Kaya Parisudha termasuk 
dalam wacika yaitu dapat menjelaskan dan menyampaikan hasil percobaan dengan benar. Hal ini sejalan dengan pendapat Mahmudah (2016:176) mengungkapkan bahwa "komunikasi berarti menyampaikan pendapat hasil keterampilan proses lainnya baik secara lisan maupun lisan”.

Temuan ini didukung hasil penelitian Mustikawati, dkk (2015), hasil penelitian yang menunjukkan terdapat pengaruh pendekatan saintifik terhadap hasil belajar ke terampilan menyimak dalam mata pelajaran Bahasa Indonesia tema Cita-citaku siswa kelas IV di SDN Desa Peguyangan ditinjau dari jenis pertanyaan guru. Dan hasil penlitian Sariani, dkk (2018) yaitu hasil penelitian menunjukkan bahwa terdapat perbedaan yang signifikan hasil belajar matematika antara kelompok siswa yang dibelajarkan menggunakan model pembelajaran CTL berorientasi Tri kaya Parisudha dan kelompok siswa yang tidak dibelajarkan menggunakan model pembelajaran CTL berorientasi Tri kaya Parisudha pada siswa kelas III SD di Gugus III semester II Kecamatan Banjar Kabupaten Buleleng tahun pelajaran 2017/2018.

Berdasarkan paparan di atas, maka dapat disimpulkan bahwa terdapat pengaruh yang signifikan secara simultan pendekatan saintifik berorientasi Tri Kaya Parisudha terhadap penguasaan konsep IPA dan keterampilan proses sains pada siswa kelas V di Gugus VII Kecamatan Sukasada Kabupaten Buleleng Tahun Pelajaran 2018/2019.

\section{Simpulan}

Berdasarkan hasil pengujian hipotesis dan pembahasan, maka simpulan dari penelitian ini adalah sebagai berikut. (1) terdapat pengaruh yang signifikan pendekatan saintifik berorientasi Tri Kaya Parisudha terhadap penguasaan konsep IPA pada siswa kelas V di Gugus VII Kecamatan Sukasada Pelajaran 2018/2019. Rata-rata nilai penguasaan konsep IPA di kelas eksperimen sebesar 81,48 dan tata-rata penguasaan konsep di kelas kontrol sebesar 70,09. Dari hasil uji Anava satu jalur juga dapat diketahui bahwa diperoleh nilai sig. sebesar Fhitung $=32,27>$ Ftabel $=4,00$. Dengan demikian pendekatan saintifik berorientasi Tri Kaya Parisudha berpengaruh terhadap penguasaan konsep IPA siswa. (2) terdapat pengaruh yang signifikan pendekatan saintifik berorientasi Tri Kaya Parisudha terhadap keterampilan proses sains pada siswa kelas V di Gugus VII Kecamatan Sukasada Pelajaran 2018/2019. Rata-rata nilai penguasaan konsep IPA di kelas eksperimen sebesar 83,67 dan tata-rata penguasaan konsep di kelas kontrol sebesar 80,66. Dari hasil uji Anava satu jalur juga dapat diketahui bahwa diperoleh nilai sig. sebesar Fhitung $=9,64>$ Ftabel $=4,00$. Dengan demikian pendekatan saintifik berorientasi Tri Kaya Parisudha berpengaruh terhadap keterampilan proses sains siswa. (3) terdapat pengaruh yang signifikan secara simultan pendekatan saintifik berorientasi Tri Kaya Parisudha terhadap penguasaan konsep IPA dan keterampilan proses sains pada siswa kelas V di Gugus VII Kecamatan Sukasada Pelajaran 2018/2019. Dari hasil uji Manova diketahui bahwa diperoleh nilai sig. sebesar nilai F Pillai's Trace, Wilks' Lambda, Hotelling's Trace, Roy's Largest Root adalah 23,699 seluruhnya memiliki signifikansi 0,000 dan lebih kecil dari 0,05 $(0,000<0,05)$, sehingga H0 ditolak dan H1 diterima. Hal ini berarti, terdapat pengaruh yang signifikan secara simultan pendekatan saintifik berorientasi Tri Kaya Parisudha terhadap penguasaan konsep IPA dan keterampilan proses sains pada siswa kelas V SD Gugus VII Kecamatan Sukasada Kabupaten Buleleng.

Berdasarkan pemaparan di atas, dapat disimpulkan bahwa terdapat pengaruh yang signifikan secara simultan pendekatan saintifik berorientasi Tri Kaya Parisudha terhadap penguasaan konsep IPA dan keterampilan proses sains pada siswa kelas V SD Gugus VII Kecamatan Sukasada Kabupaten Buleleng.

Berdasarkan hasil penelitian ini, maka dapat diajukan beberapa saran sebagai tindak lanjut dari penelitian ini adalah (1) Kepada guru disarankan agar menerapakan pendekatan pembelajaran saintifik berorientasi Tri Kaya Parisudha karena hasil penelitian membuktikan bahwa penggunaan pendekatan pembelajaran saintifik berorientasi Tri Kaya Parisudha meningkatkan penguasaan konsep IPA dan keterampilan proses sains siswa. (2) Kepada kepala sekolah, agar dapat menggunakan hasil penelitian ini sebagai bahan ruefrensi dalam melaksanakan pembelajaran dengan menggunakan pendekatan pembelajaran untuk meningkatkan penguasaan konsep IPA dan keterampilan proses sains siswa. (3) Kepada peneliti lain, dapat menggunakannya sebagai refrensi dalam penelitian yang sejenis ataupun yang tidak.

\section{Daftar Pustaka}

Agustiana, G. A. T \& Tika, I. N. 2013. Konsep Dasar IPA Aspek Fisika Dan Kimia. Yogyakarta: Ombak.

Batmalo, J. B. 2016. "Implementasi Pendekatan Saintifik Dalam Pembelajaran Tematik Integratif Pada Kelas V Sekolah Dasar Negeri Nirmala Bantul. Jurnal PGSD. Vol.6, No. 5. Tersedia pada: http://journal. student.uny.ac.id. Diakses, 18 Juni 2019.

Machin, A. 2014. "Implementasi Pendekatan Saintifik, Penananman Karakter Dan Konservasi Pada Pembelajaran Materi Pertumbuhan. Jurnal Pendidikan IPA Indonesia. Vol. 3, No. 1. Tersedia pada: http://journal. unnes.ac.id/nju/index.php.jpii.Diakses,18 Juni 2019.

Mahmudah, L. 2016. "Pentingnya Pendekatan Keterampilan Proses Sains Pada Pembelajaran IPA Di Madrasah”. Vol. 4, No.1. Tersedia pada: http://journal.satinskudus.ac.id. Diakses, 18 Juni 2019.

Daryanto, A. 2014. Pendekatan Pemelajaran Saintifik Kurikulum 2013. Yogyakarta: Grava Media.

Mustikawati, N. D., dkk. 2015. "Pengaruh Pendekatan Saintifik terhadap Hasil Belajar Keterampilan Menyimak dalam Mata Pelajaran Bahasa Indonesia Tema Cita-Citaku pada Siswa Kelas IV di SDN Desa Peguyangan ditinjau dari Jenis Pertanyaan Guru”. e-Journal PGSD Universitas Pendidikan Ganesha. Vol. 3, No. 1. Tersedia pada: htpp:// ejournal.undiksha.ac.id. Diakses, 3 April 2019. 
Permendikbud Nomor 67 Tahun 2013 tentang Kerangka Dasar dan Struktur Kurikulum Sekolah Dasar/Madrasah Ibtidaiyah.

Sariani, N. L. A., dkk. 2018. "Pengaruh Model Pembelajaran CTL Berorientasi Tri Kaya Parisudha Terhadap Hasil Belajar Matematika Siswa Kelas III". Journal of Education Technology. Vol. 2, No. 3 (hlm 95102). Tersedia pada: https://ejournal.undiksha.ac.id/index.php/JET/article/view/16372. Diakses, 24 Januari 2019.

Setiawan, M. H. Y. 2018. "Kreativitas Pendidikan Dalam Pengelolaan Kegiatan Pada Pembelajaran Saintifik Pada Implementasi Kurikulum PAUD 2013. Jurnal Audi. Vol. 3, No. 2. Tersedia pada: http://ejurnal.unisari. ac.id/index.php/jpaud. Diakses, 18 Juni 2019.

Utami, A. U. \& Murti, S. C. C. 2018. "The Effectiveness Of Scientific Approach-Based Science Learning Materials To Educate Students Science Literacy”. JPPS (Jurnal Penelitian Pendidikan Sains). Vol. 8, No.1. Tersedia pada: https://journal.unesa.ac.id/index.php/jpps/article/view/3859. Diakses, 24 Januari 2019.24 Januari 2019.

Undang-undang No. 20 Tahun 2003 tentang Sistem Pendidikan Nasional. 